\title{
9 Socialist Encounters at the School of Friendship
}

\begin{abstract}
Education is our principal instrument in forming the New Man; a man, liberated from old ideas, from a mentality that was contaminated by the colonial-capitalist mindset; a man educated by the ideas and practices of socialism. ${ }^{1}$
\end{abstract}

Mozambican President Samora Machel

When Mozambique achieved independence in 1975, there arose new opportunities for knowledge exchange and socialist encounters in the education sector. The socialist alignment of the Mozambican Liberation Front (FRELIMO) allowed the country to tap into international knowledge networks connecting socialist countries across the world. Young Mozambicans attended schools in Cuba and the German Democratic Republic (GDR), while adults received vocational and military training or attended universities all over the Eastern Bloc, as part of state-initiated knowledge transmission migrations. ${ }^{2}$ The idea for the School of Friendship (Schule der Freundschaft, SdF) was born in FRELIMO leadership circles at the end of the 1970s. President Samora Machel (1975-86) prioritized professional education to provide the industrializing country with skilled labor in the absence of a professional working class. This was important both ideologically and practically. Not only was the working class the revolutionary class in the Marxist-socialist exegesis favored by Machel, but in the aftermath of colonial neglect of education and the exodus of Portuguese settlers, the young People's Republic of Mozambique (PRM) lacked people with professional skills. ${ }^{3}$ The SdF was to provide its 900 students with both general knowledge and vocational training to return skilled socialist workers as New Men (and Women) for the Mo-

1 Samora Machel, "Organizar a sociedade para vencer o subdesenvolvimento," [Organize society to fight underdevelopment] Colecção Estudos e Orientações 14 (1982): 4.

2 Hauke Dorsch, "Rites of Passage Overseas?: On the Sojourn of Mozambican Students and Scholars in Cuba," Africa Spectrum 43 (2008): 225-44. Prior to independence, Mozambicans had already migrated to other African countries for instance to attend school in Dar es Salaam; see Michael G. Panzer, "The Pedagogy of Revolution: Youth, Generational Conflict, and Education in the Development of Mozambican Nationalism and the State, 1962-1970," Journal of Southern African Studies 35 (2009).

3 Mathias Tullner, "Das Experiment 'Schule der Freundschaft' im Kontext der Mosambikanischen Bildungspolitik," in Freundschaftsbande und Beziehungskisten: Die Afrikapolitik der DDR und der BRD gegenüber Mosambik, ed. Hans-Joachim Döring and Uta Rüchel, (Frankfurt am Main: Brandes \& Apsel, 2005), 100.

Ә OpenAccess. () 2021 Marcia C. Schenck and Francisca Raposo, published by De Gruyter.

(c) BY This work is licensed under the Creative Commons Attribution 4.0 International License. https://doi.org/10.1515/9783110623543-009 
zambican socialist and industrial revolution. The East German Socialist Unity Party (SED) leadership also took up the idea in the late 1970s and developed the SdF, not least because this goal was congruent with the SED's political values, its aspiration to aid the socialist development of so-called brother nations, and its economic interests in Mozambique. The SdF can be read in a broader tradition of East German institutions of learning targeted at the African and international vanguard. Other examples of these institutions explored in this volume include the FDGB college in Bernau, discussed by Eric Angermann in Chapter 4, the Herder Institute, discussed by Jörg Depta and Anne-Kristin Hartmetz in Chapter 2, and the higher education student exchanges discussed by Christian Alvarado in Chapter 3.

Existing studies dedicated specifically to the SdF are overwhelmingly based on the German archival record and aim to understand what the experiment can tell us about the successes and failures of schooling children from socialist brother states. ${ }^{4}$ Some researchers have given particular attention to the socialist dimension of this education migration project. ${ }^{5}$ Education scholars focus on the education aspect. ${ }^{6}$ This contribution combines an analytical section with a firsthand account and is divided into two parts. The first provides background and historical context to understand the second part. This second section, which, similarly to Chapter 10, delves into one life-history, is a first-person account by a former student of the SdF, Francisca Raposo. Ms. Raposo pays particular attention to the process of her unmooring from Mozambican life to prepare for her new life in the GDR. She describes how she navigated personal disentanglements from familiar social structures and contexts, while forming new connections as she made new friends from all over Mozambique even before she arrived in the GDR. We can interpret her account using the metaphor of mooring and unmooring, discussed in the introduction to this volume. The metaphor comes into play here both in a spatial and a temporal sense.

4 See Annette Scheunpflug and Jürgen Krause, Die Schule der Freundschaft: Ein Bildungsexperiment in der DDR, Beiträge aus dem Fachbereich Pädagogik der Universität der Bundeswehr Hamburg (Hamburg: Universität der Bundeswehr Hamburg, 2000); Lutz R. Reuter and Annette Scheunpflug, Eine Fallstudie zur Bildungszusammenarbeit zwischen der DDR und Mosambik (Münster: Waxmann Verlag, 2006).

5 Uta Rüchel, “...Auf Deutsch sozialistisch zu denken...” - Mosambikaner in der Schule der Freundschaft, ed. Die Landesbeauftragte für die Unterlagen des Staatssicherheitsdienstes der ehemaligen DDR in Sachsen-Anhalt (Magdeburg: JVA Naumburg - Arbeitsverwaltung, 2001); Tanja Müller, Legacies of Socialist Solidarity: East Germany in Mozambique (Lanham, Md: Lexington Books, 2014).

6 Scheunpflug and Krause, Die Schule der Freundschaft: Ein Bildungsexperiment; Reuter and Scheunpflug, Eine Fallstudie. 
Why did 900 young Mozambicans have to travel thousands of kilometers northward to attend an East German school to become skilled workers? For the FRELIMO leadership circle, establishing the school in Mozambique was out of the question, due to the ongoing war, a scarcity of internship opportunities, and funding challenges. Under these circumstances, it did not seem possible to maintain an isolated school with elite conditions in the country itself - it was more prudent to transfer the children. The SdF was to be a vision of Mozambique's scientific-Marxist future, one in which "tribalism," "occultism," and "poor work routine" were to be overcome and Mozambican traditions were to become nothing but folklore. ${ }^{7}$ The few hundred square meters of an idealized Mozambique, embodied in the school's campus in Staßfurt, were dedicated to the socialist venture of educating the New Man. ${ }^{8}$ In the language of the time, it was a symbol of international solidarity, but it also played into the political and economic interests of the GDR. ${ }^{9}$ The content and concept of the SdF were intentionally left in German hands; Mozambique was interested in East German, not Mozambican, standards. ${ }^{10}$ This produced an in-betweenness, where an idealized Mozambique was constructed in Staßfurt. The school remained isolated, foreign visitors were not allowed in, and initially the Mozambican students were only allowed to go out in supervised groups. Thus the young migrants traversed a whole continent, only to find themselves practically immobile, at least in the beginning. ${ }^{11}$ As the students became older and spoke better German, they were able to leave the premises by themselves, especially to visit their East German host families, or friends at the weekends. Many students remember their overall experience in a rather positive light, but they were also subjected to racism and found their freedom curtailed in other ways. For instance, the possibilities for students to enact their faiths or live in accordance with religious commandments were limited at best. ${ }^{12}$ This is, therefore, a case study for political

7 Allen F. Isaacman and Barbara Isaacman, Mozambique: From Colonialism to Revolution, 1900-1982 (Boulder: Westview Press, 1983), 93-99.

8 Tullner, "Das Experiment 'Schule der Freundschaft'," 103.

9 Katrin Lohrmann and Daniel Paasch, "Die 'Schule der Freundschaft' in Staßfurt," in Freundschaftsbande und Beziehungskisten, ed. Hans-Joachim Döring and Uta Rüchel (Frankfurt am Main: Brandes \& Apsel, 2005), 95-98.

10 Tullner, "Das Experiment 'Schule der Freundschaft'," 105.

11 Scheunpflug and Krause, Die Schule der Freundschaft: Ein Bildungsexperiment, 82, 128.

12 Müller, Legacies of Socialist Solidarity, 86-90; Marcia C. Schenck, "Small Strangers at the School of Friendship: Memories of Mozambican School Students to the German Democratic Republic," Bulletin of the GHI 15 (2020): 49-50; Emilia Francisco, “A Presença de Skinheads em Stassfurt?," in Moçambique - Alemanha, Ida e Volta: vivências dos moçambicanos antes, durante e depois de estadia na Alemanha, ed. Ulf Dieter Klemm (Maputo: ICMA, 2005), 81-84. 
entanglements between two countries but on the social level of the school project entanglements remained temporary encounters, transitory moorings rather than roots. This story ended with political disengagement of the two governments, a process that reverberated on the individual level long after the participants had returned to Mozambique.

Who were the students, like Francisca Raposo, and how were they recruited and selected? The Mozambican Minister of Education, Graça Machel, had the prospective students recruited from across provinces to foster the unity of the Mozambican nation state which the government was trying to create. ${ }^{13}$ Students were often approached in their local schools, as Francisca describes in her account. Once they were convinced, they often had to persuade their parents, many of whom were afraid of selling their children into slavery: a fear based on their and their ancestors' experience with Portuguese colonialism, forced labor, and slavery. ${ }^{14}$ Other parents placed their trust in the FRELIMO government and immediately supported their children's decision to pursue their education abroad. ${ }^{15}$ Francisca's experience lay somewhere in the middle of these extremes. What drew many children, including Francisca, was a thirst for adventure, the will to leave behind a life of relative poverty, and a desire to further pursue their education. ${ }^{16}$ Most, like Francisca, were making a leap into the complete unknown.

As regards the operation of the SdF, in the summer of 1982 a total of 900 Mozambican children arrived in Staßfurt. They were between 12 and 14 years of age, and had completed at least a fourth-grade education in Mozambique. Contrary to official documentation, the new students did not constitute a homogeneous group. Rather, the 200 girls and 700 boys, from all over Mozambique, arrived with various levels of education and an actual age range of nine to $16 .{ }^{17}$ The result was a potpourri of religions, languages, customs, and class origins. This diversity was, however, all but ignored. The students were to grow into socialist Mozambican citizens, overcoming ethnic and religious identities. It was irrelevant whether they were Makonde or Makua, Shangaan or Shona, animist, Muslim, or Christian. For the students, this meant that by the time they were brought together in holding centers all over Mozambique-even prior to reaching Maputo-their ties with their home regions, languages, and customs were slowly loosened and they learned, as

13 Tullner, "Das Experiment 'Schule der Freundschaft'," 103.

14 Albino Forquilha, interview conducted by the author, Maputo, September 2, 2011; Pedro Munhamasse, interview conducted by the author, Quelimane, June 7, 2014.

15 Forquilha, interview.

16 Pedro Munhamasse, Pascoa Rodrigues, and Narguice Ibrahim Jamal, interview conducted by the author, Quelimane, June 8, 2014.

17 Reuter and Scheunpflug, Eine Fallstudie, 78. 
Francisca vividly describes, to engage on new terms with children from all over the country. As Francisca left her home region further behind, the group diversity increased and she gradually had to communicate in Portuguese and concentrate on what she shared with the other children: being young, curious Mozambican citizens. ${ }^{18}$ The more Francisca and the children met children with other mother tongues, customs, and lived realities, the more they were encouraged to shed these distinguishing features and to form a new identity: that of a shared Mozambican-ness. This process was intensified once they were living and studying in the closed cosmos of the SdF, in a small East German village. The aim was to become Mozambique's vanguard workforce of the future.

In Francisca Raposo's contribution, we are invited to step into her shoes as a Mozambican girl, not yet a teenager. For her this story was decidedly not a political story about education cooperation between brother nations, but a personal story of liberation and emancipation from a life of work and service to family members. Her tools of liberation were her mind - she was always an excellent student - and the opportunity to travel to the GDR. The story Francisca chooses to share leaves no doubt that she sees her child-self as the main protagonist. In other words, it was her who made the decision to leave at all costs and managed to talk her parents into letting her go. The larger political context, socialism, and government agreements play no role in her story. Her account highlights the level of misinformation, rumors, and speculation that were rife in the general population in Mozambique as regards to the government's international education initiatives. Despite all the distorted reports that young Francisca heard about the GDR, she chose to trust in the information her teachers provided and placed all her hopes and anticipations for a better life in her journey to an unknown land. There is, however, more context and background to these rumors (p. 242) than Francisca knew when she came across them as a girl. There is a long history of rumors in different parts of Africa asserting that slavers were cannibals. ${ }^{19}$ Witches and vampires served as metaphors to talk about exploitation and reveal anxieties and concerns of those speaking about them. ${ }^{20}$ Where violence was concerned, fact and fiction often merged. ${ }^{21}$ These rumors likely then indicate, in the minds of those spreading them, a continuity between the

18 Munhamasse, interview.

19 John Thornton, "Cannibals, Witches, and Slave Traders in the Atlantic World," The William and Mary Quarterly 60 (2003).

20 Luise White, Speaking with Vampires: Rumor and History in Colonial Africa, Studies on the History of Society and Culture (Berkeley, Cal.; London: University of California Press, 2000). 21 Ann Laura Stoler, “'In Cold Blood': Hierarchies of Credibility and the Politics of Colonial Narratives,” Representations 37 (1992). 
slave trade, colonialism, and the GDR. Despite official rhetoric that the new partners in the socialist east (who claimed to be anti-racist and anti-imperialist) were to be radically different from the former colonizers, people appear to have been less than convinced, as they continued to associate overseas countries with white inhabitants with a centuries-long history of forced migration, labor exploitation, and unfreedom. This might open up a new perspective on stories told by migrants to the GDR about racism and exploitative working conditions. On the other hand, this particular form of labor migration had only been active for two years at the time when Ms. Raposo heard these rumors.

This story focuses on the long path that young Francisca had to travel before she ever set foot on East German soil. With that, this contribution deals with a little-explored topic, namely the migration process from selection to arrival at the SdF. Francisca Raposo reflects on her childhood as a girl growing up in central Mozambique between the Zambezi River and the city of Quelimane. She also presents her perspective as one of the only 200 female students at the SdF. Another important feature of her story is its theme of unity between the students from all walks of life and all corners of Mozambique. This unity of the student body, which was later to become a socialist collective, is something that alumni all over Mozambique continue to emphasize to the present day, and which even led to the establishment of many alumni groups across the country. ${ }^{22}$ The special connection that many former students maintain with one another, but also with the SdF as an institution and with Germany, as heir to the GDR, is also a motivation for women like Ms. Raposo who chose to travel across continents again to speak about her time as a student at the School of Friendship, 30 years after her return to Mozambique. In contributing her recollections to this volume, she also chose to defy personal circumstances and the personal consequences of devastating cyclones, demonstrating the importance of her SdF experience to her personal story.

What follows now is Francisca Raposo's narrative: $:^{23}$

22 Müller, Legacies of Socialist Solidarity, Chapter 3; Schenck, "Small Strangers," 57. During 2015, Marcia C. Schenck spent six months travelling through Mozambique and interviewed just about 200 returned workers, school children, and students who had spent part of their formative years in the GDR. In the process she met with many active alumni groups.

23 Thank you to Immanuel Harisch and Marcia C. Schenck for providing feedback and editing the narrative and to Marcia Schenck for translating it from German into English. Marcia C. Schenck and Francisca Raposo met at the conference "Respekt und Anerkennung" (Respect and Acknowledgement) in Magdeburg, Germany, February 22-24, 2019. Ms. Raposo agreed to 


\section{A Long Way to School: My Memories of Making My Way to the GDR}

In December 1981, my school director announced that the government would select the best students between 11 and 13 years of age to fly to the German Democratic Republic to continue their studies. I lived in a small village called Conho, which is located 18 kilometers from the town of Mopeia. I was almost 13 years old at the time. At the time, in fifth grade, I was one of the best students in my class. I did not know what GDR meant and could not even imagine what the country looked like. But I was curious and wanted to go.

I really wanted to fly far away with other students because my life at home was not easy. I lived with my aunt and had to do a lot of housework and take care of my cousins. Sometimes I also lived with my grandmother, the mother of my father. I had to go to the forest for firewood with my friends. We didn't have an electric cooker or a gas stove. To buy school supplies, I had to work in the fields to earn money. Once I was given a lot of school materials as a gift because I was one of the best students. That was a relief for me, but I had to share some school materials with my brothers and sisters. My older sister studied in another school, in another place called Luabo. We saw little of each other. She was in a dormitory and sometimes, when she had no money to pay for the dormitory, she lived with my aunt, my mother's sister.

\section{The Dream of the Unknown}

Given this life at home, the option of flying to the GDR was a relief for me - and a very big chance. I was a girl with no concept of the GDR, but that didn't interest me. Whether it looked nice there or not, whether there were nice people or not, none of that mattered to me. I only wanted to go to the GDR - that became my primary goal.

Finally, the six best students between 11 and 13 years among us were chosen. Our parents were informed by the school director about our trip. At first, my parents did not agree to my leaving, because they had no idea what it meant to learn in the GDR either. Illiteracy was a problem for my parents' generation

write a contribution for this book. During the writing process, she was hit hard by Cyclone Idai, family tragedies, and the Corona pandemic, which made writing much more challenging than anticipated. 
and the population in Mozambique in general at the time. Thus, speculation was rife and wrong attitudes about white people prevailed. For example, people were convinced that the GDR made sardines out of us. Some children, people said, will return to Mozambique in crates, or we will never return home at all. I was not scared easily. For me it didn't matter whether they made sardines out of me or killed me, I just wanted to get away from what to me was an unbearable life. To dispel the rumors and allow us children to go, the headmaster tried to explain to the people that it was not true that people were making sardines or something else out of us. He also said that white people do not eat human flesh, but many didn't believe it. It was clear to my parents that it was unlikely we would end up as sardines because they trusted the government. Yet, my mother still didn't want me to fly to the GDR but eventually, after many explanations, she agreed.

\section{An Inner Mozambican Odyssey to the GDR... Quelimane first}

After our parents agreed, we thought we were ready to go; but before we could start, we had to have many health checks. Fortunately, I was healthy and so were my fellow students. Next we all had to go to Quelimane, the state capital, where we met other students from other county towns. When we finally arrived in Quelimane one evening, everyone was tired and exhausted but also curious about what was waiting for us. I already knew Quelimane because I had been there several times with my aunt. It is a very beautiful city with many coconut trees.

In Quelimane I started a different life, without my aunt, my cousins, without my brothers and sisters, and without housework. The girls were separated from the boys. We were placed in a boarding school. After three days we could visit the boys. Our boarding school was small and better than the boys'. In the meantime, students from different districts of the Zambézia Province also came. They looked just like me: exhausted and curious. We immediately made friends and learned our names. All the girls were very nice and everyone wanted to know about everything. Each of us spoke about life at home and at school, about what we wanted to play and other such matters on the mind of young girls. I quickly made new girlfriends: Arminda, Laura, Narguisse, Bernadette, Gloria, Angelina, Laurinda, and others. We were treated very well and had enough to eat. Although the boys were in a different home, we almost always met. 


\section{... Then onto Nampula}

After staying in Quelimane for about three weeks we went to Nampula. There, in the north of Mozambique, we stayed for three months. The trip to Nampula was not as easy as I had imagined because the roads were in very bad condition. Once in Nampula, we were to meet other students from other provinces, namely from Cabo Delgado, Niassa, and also Zambézia. Once again a new life began for me - different faces, many different languages, different habits, and expectations. In Mozambique, each province and even subregions have their own language, but everybody uses Portuguese to communicate and so it was the same for us.

\section{... And Finally Maputo}

When three months had passed, we had to travel again, this time by plane to Maputo, the capital of Mozambique. It was not the first time I flew, because I had flown once before from Quelimane to Beira together with my aunt. ${ }^{24}$ But for most of the others, it was the first time and they were afraid.

In Maputo I met even more children from yet other provinces: Maputo, Tete, Sofala, Inhambane, Gaza, Cabo Delegado, Niassa, Nampula, Manica, and Zambézia. Now the whole country was gathered. And we all established friendships despite the many new languages, new faces, new cultures, and new habits. We were housed in a home called Pousada dos Caminhos de Ferro de Moçambique. The home belonged to the Mozambican railway. We were about 1,500 students. Five hundred of them flew to Cuba and only 900 were allowed into the GDR. This meant that 100 students were too many - once we learned that nobody slept peacefully anymore. We were so afraid that our name might not be on the right list, or worse yet, on no list at all. It didn't help matters that we stayed in Maputo for about four or five months. We had to do different examinations again but otherwise spent a lot of time waiting and fretting about who would go. After about two months, people from the ministry came with lists and passports. All of us were called to gather. They told us that this time a group of 70 students could fly. I was glad of that. I thought this time I was going to fly for sure. The names were read out, from one to seventy, but my name was not among

24 Flying was something very special to be remembered by every child in this story. At the same time, given the civil war, it was the only safe way to travel between the provinces for much our post-independence history and whoever could afford it would prefer that way of travel. 
them. Every time new groups were read out, I intently listened for my name, but every single time I was disappointed and left even more anxious than before. Eventually, my name was read out in the ninth group. I was thrilled and beside myself with relief, joy, and expectation. But I did not have much time for feelings as I had to prepare for the journey.

The day of all days then came quickly. We took a truck to the airport. I was trembling all the time because I was afraid that someone would tell me I wasn't allowed to fly because I was sick, or the names got mixed up, or something similar. But our flight left Maputo at 10:00 a.m.

\section{And Then - My First Night in the GDR}

Between 11:00 p.m. and 12:00 a.m. we finally landed in Berlin. It was the middle of the night, and pitch dark, but I could see many things because of the lights. I saw a very large city with so many colorful lights I had never seen before. We slept in a hotel in Berlin, well most of us didn't sleep that much. But the next day, we drove on to the village of Staßfurt, to the School of Friendship, where our colleagues, educators, and teachers were already waiting for us. And there we finally arrived.

\section{Bibliography}

Dorsch, Hauke. "Rites of Passage Overseas? On the Sojourn of Mozambican Students and Scholars in Cuba." Africa Spectrum 43 (2008): 225-244.

Francisco, Emilia. A Presença de Skinheads em Stassfurt? Moçambique - Alemanha, Ida e Volta: vivências dos Moçambicanos antes, durante e depois de estadia na Alemanha, edited by Ulf Dieter Klemm, 81-84. Maputo: Instituto Cultural Mocambique - Alemanha (ICMA), 2005.

Isaacman, Allen F., and Barbara Isaacman. Mozambique: From Colonialism to Revolution, 1900-1982. Boulder, Colo: Westview Press, 1983.

Lohrmann, Katrin, and Daniel Paasch. "Die 'Schule der Freundschaft' in Straßfurt." In Freundschaftsbande und Beziehungskisten: die Afrikapolitik der DDR und der BRD gegenüber Mosambik, edited by Hans-Joachim Döring and Uta Rüchel, 91-99. Frankfurt am Main: Brandes \& Apsel, 2005.

Machel, Samora M. "Organizar a Sociedade para Vencer o Subdesenvolvimento." Colecção estudos e orientações 14 (1982).

Müller, Tanja. Legacies of Socialist Solidarity: East Germany in Mozambique. Lanham, Md: Lexington Books, 2014. 
Panzer, Michael G. "The Pedagogy of Revolution: Youth, Generational Conflict, and Education in the Development of Mozambican Nationalism and the State, 1962-1970." Journal of Southern African Studies 35 (2009): 803-820.

Reuter, Lutz-Rainer, and Annette Scheunpflug. Eine Fallstudie zur Bildungszusammenarbeit zwischen der DDR und Mosambik. Münster, New York, Munich, Berlin: Waxmann Verlag $\mathrm{GmbH}, 2006$.

Rüchel, Ute. “...auf deutsch sozialistisch zu denken...” - Mosambikaner in der Schule der Freundschaft. Magdeburg: JVA Naumburg - Arbeitsverwaltung, 2001.

Schenck, Marcia C. "Small Strangers at the School of Friendship: Memories of Mozambican School Students to the German Democratic Republic." Bulletin of the GHI 15 (2020): 41-59.

Scheunpflug, Annette, and Jürgen Krause. Die Schule der Freundschaft: ein Bildungsexperiment in der DDR. Hamburg: Universität der Bundeswehr Hamburg, 2000.

Stoler, Ann Laura. “'In Cold Blood': Hierarchies of Credibility and the Politics of Colonial Narratives." Representations 37 (1992): 151-189.

Thornton, John. "Cannibals, Witches, and Slave Traders in the Atlantic World." The William and Mary Quarterly 60 (2003): 273-294.

Tullner, Mathias. "Das Experiment 'Schule der Freundschaft' im Kontext der mosambikanischen Bildungspolitik." In Freundschaftsbande und Beziehungskisten: die Afrikapolitik der DDR und der BRD gegenüber Mosambik, edited by Hans-Joachim Döring and Uta Rüchel, 100-109. Frankfurt am Main: Brandes \& Apsel, 2005.

White, Luise. Speaking with Vampires: Rumor and History in Colonial Africa. Studies on the History of Society and Culture. Berkeley, Cal.; London: University of California Press, 2000. 
